\title{
Direct and Indirect Benefits of an International Service-Learning Design Project: Educational Effects on Project Members and Their Peers
}

\author{
Peter E. Johnson \\ Assistant Professor of Mechanical Engineering \\ Valparaiso University \\ Valparaiso, IN 46383 \\ Pete.Johnson@valpo.edu
}

\begin{abstract}
It has been well documented that international service-learning design projects in engineering provide many educational benefits to the students involved in these projects. This article addresses the question of whether or not the benefits gained from international service-learning design projects extend to those students who are not directly involved with these projects but are peers of those who are. To answer this question, graduates of the senior design projects course at Valparaiso University from 2003 to 2008 were surveyed on the course learning objectives, their desire to participate in service-related activities, and their social and cultural awareness. The responses from this survey show that peers of students who experienced an international service-learning design project developed a stronger desire to participate in service-related activities than those alumni who experienced the course when an international service-learning design project was not offered. The responses also show that these same peers felt they were more aware of societal issues and other cultures as well. This article discusses the senior design course, the international service-learning design project, the survey, the results of this survey, and suggested improvements that will extend the benefits of an international service-learning design project beyond those students with direct involvement to their peers.
\end{abstract}

Index Terms - Engineering education, international, multi-disciplinary, senior design, servicelearning.

\section{INTRODUCTION}

As our world becomes smaller, more engineering educators are introducing international service projects into their curricula [Borg, 2008; Freeman, 2006; Green, 2004; Jiusto, 2006; Johnson, 2007a-b; Phillips, 2007; Vader, 1999]. The motivations behind these projects are diverse, but many projects are developed to provide a service to a community in need and to provide international exposure and real-world project experiences for their students. Secondary benefits such as increased social and cultural awareness and a stronger desire for service are often expected in these students as well.

Valparaiso University is a small, comprehensive university located in Northwest Indiana. During the academic calendar years from 2005-06 to 2007-08 at Valparaiso University, teams of students enrolled in GE 497/498 Senior Design Project I and II designed and installed wind turbines in three different communities on Ometepe Island, Nicaragua [Johnson, 2007a-b]. To determine the effects that these projects had on the peers of those students who traveled to the island, a survey was conducted of 133 alumni who had participated in the senior design course 
sequence from the fall 2002 semester to the spring 2008 semester. During the first two academic years, 2002-03 to 2003-04, no international service learning projects were proposed. The alumni results from these years were used as a baseline study. In the other four academic years, the Ometepe Project was offered and therefore alumni responses were divided into those students directly involved in the project and those that were not. The survey results suggest that the Ometepe Project not only had a positive impact on the students directly involved in the project, but also on their peers who were involved in other projects in this course. The benefits that extend to the peers of the Ometepe Project are specifically in the areas of social and cultural awareness and service with no loss in achievement of the course learning objectives.

This article will briefly describe the senior design course at Valparaiso University including an overview of the Ometepe Project. The survey that was given to the six graduating classes of alumni who have been involved in the senior design course will also be explained. Finally, it will be shown that the Ometepe Project has not only been influential in the educational development of the students directly involved in the project but also of their peers.

\section{BACKGROUND}

As international service-learning projects in engineering disciplines become more popular, a number of instructors have explored the benefits that these projects provide to the students including the exposure to new cultures and to different construction practices [Borg, 2008; Freeman, 2006; Green, 2004; Jiusto, 2006; Johnson, 2007a-b; Phillips, 2007; Vader, 1999]. Some have carefully gathered quantitative information from the students who travel [Phillips, 2007; Borg, 2008]. For example, Phillips, et. al., [2007], performed a pre- and a post-trip assessment of students who worked on an international service-learning design project. Changes in the survey responses and entries from journals written during the trip suggest that this service experience helped these students meet ABET Criterion 3 which addresses the skills, knowledge, and behaviors that graduates should have [ABET, 2004]. Borg and Zitomer [2008] collected data through pre- and post-trip surveys, and they reviewed journal entries of students who worked on an international service-learning experience in Guatemala. Various readings were assigned to prepare the students for the cultural and economic adjustment they would experience. The preand post-trip survey results showed a surprising decrease in student ratings of four of the 11 learning objectives related to ABET Criterion 3. Borg and Zitomer suggest that the reason behind these decreased ratings was often due to the frustration that can occur when students are thrown into a completely new environment. Teamwork and communication can become challenging when working with simple tools and without the conveniences that are typically available. In these cases, journal entries illustrate the significant learning that occurred despite the decrease in the students' ratings.

Other instructors have chronicled their experiences with international service-learning trips from a more qualitative perspective [Vader, 1999; Freeman, 2006; Green, 2004]. For example, Vader, et. al., [1999] qualitatively assessed an international service project in which a student team installed a photovoltaic electric power plant in a village in Burkina Faso. The authors determined opportunities for improvement in the project implementation, including more deliberate instruction in project management, teamwork, and testing. Green et. al., [2004] took a broader approach by assessing the international humanitarian design projects of four faith-based institutions. By determining the similarities in these projects, they were able to provide insight for those looking to optimize the project selection process for team success. Finally, the value of 
including non-engineers in an international design project was addressed by Freeman, et. al. [2006]. The authors compiled journals from team members who experienced a design project for a village in China and found that non-engineers involved in the project provided an added benefit to the team. In the assessment of this trip, the authors also recognized that non-traveling members of the team "can have the same team-building experiences, leadership, personal growth, and a feeling of accomplishment as those that traveled."

\section{VAlParaiso University Senior Design Projects I AND II}

Students in electrical, computer, and mechanical engineering at Valparaiso University are required to complete a two-semester senior design project experience - GE 497/498 Senior Design Project I and II [Hagenberger, 2007; Johnson, 2007 a-b; Tougaw, 2002, 2003, 2005, 2007]. Prior to the start of Fall classes, faculty compile a list of available projects that typically involve a mixture of service-based projects, industry-sponsored projects, faculty research projects, projects for national student design competitions, and other academic projects. Multidisciplinary teams are created based on student preferences - each student submits his/her top four projects in order, a preferred team mate, and an individual they would prefer not to have on their team. Based on this feedback, the faculty members then create teams of four to six students.

Although the students tend to think the course is entirely about fabricating a working prototype, the pedagogical emphasis is on the design process: from problem definition and creation of a conceptual design through construction and testing of a prototype to documentation of the project. Due to time constraints, students do not physically close the loop of the design cycle by re-designing their project based on the results of the testing. However, they are required to think through this last phase of the design process in the documentation of their entire project experience. Throughout the two-semester sequence, extensive communication is required, including individual and team presentations, written proposals and final reports, and the creation of a team video and a team poster, both of which are presented to the local community at the Valparaiso University College of Engineering Design Exposition. The teams meet on a regular basis with their faculty advisor, and all students in the course meet together as a class throughout the school year. The purpose of these latter meetings is for faculty to present information to all of the students simultaneously. They include lessons on such topics as the design process, various documentation and analysis methods, brainstorming techniques, and others. Formal presentations are made by each team to the entire class three times during the year. During these presentations, all students in the course are required to actively participate by listening closely and asking questions. Similarly, ten individual presentations are made, two by each member of each team. As with the formal presentations, students are encouraged to pay close attention to the speaker and to provide feedback.

The course structure and content have gone through incremental changes between 2001 and 2008. The most significant of these occurred during the summer of 2003 and during the summer of 2007. During these changes, the learning objectives for both semesters of the two-course sequence remained unchanged. The learning objectives for GE 498, the second course, were included in the alumni survey to determine if changes to the course structure resulted in any significant changes to the student self-assessment. These learning objectives state that upon completion of GE 498, students will be able to:

- Function effectively as a member of a multidisciplinary team. 
- Build a physical prototype of a design based on engineering drawings, flowcharts, and circuit schematics.

- Effectively present oral progress reports.

- Write a technical document to summarize your design, prototype, and test results.

- Prepare and present an effective technical oral report to summarize your work.

- Use design specifications and a test plan to evaluate the success of a physical prototype.

- Incorporate engineering standards into your design project.

- Create quality audio/visual materials to support oral presentations and written reports.

- Identify important parameters to be measured to check if your design requirements are met.

- Synthesize and integrate previous knowledge in mathematics, science, and engineering to assist in the achievement of a successful design.

- Prepare a budget and cost analysis of your project.

\section{A. The Ometepe Project}

In Fall 2004, a project to create an environmentally friendly power supply for a remote community on Ometepe Island in Nicaragua was proposed to the students involved in senior design. Two electrical and three mechanical engineering students were assigned to the Ometepe Project in August of 2004. The overall project design goal was to create a wind turbine for the residents of La Palma, a small village on Ometepe Island without available power. The power requirements for this project consisted of generating enough energy to power lights in a small health clinic and a classroom for adult education classes and for an emergency radio to call for an ambulance from the nearest hospital on the island. A major design constraint was budgetary considerations. Inexpensive components were required so that the student design could be manufactured by residents of La Palma. Due to budgetary constraints, sending a group of students to Ometepe Island was not introduced as an option during this first attempt at this project. Unfortunately, the system that was developed did not produce enough power to meet the design goals set forth for the project.

The strict budgetary constraint for the teams was lifted when the Ometepe Project was offered in 2005-06, 2006-07, and 2007-08 [Johnson, 2007a-b]. In all three years, teams of two electrical and three mechanical engineering students were assigned to the project. Lifting the budgetary constraint of the project allowed the teams to focus on designing a functional system at the expense of creating a system that was more complex and therefore not as easy to maintain by the local residents. This tradeoff was deemed necessary to accomplish the primary goal of the project - designing a system that would generate the power needed by the community.

Each year included slight variations to the project - the teams went to different locations on the island and the latest team was given limited access to designs from the 2005-06 and 2006-07 designs. Before they completed their conceptual design, the 2007-08 team was given access to the final project reports for the 2005-06 and 2006-07 teams. This provided the 2007-08 team with a more explicit chance to close the loop of the design cycle by allowing them to more directly learn from previous implementations.

Furthermore, a considerable addition to the project budget was the opportunity to travel to the island to install the system if the necessary travel funding could be raised. All three of the teams that traveled raised between $\$ 12,000$ and $\$ 15,000$ for costs associated with travel to the island, designed systems that met their design requirements, and installed their prototypes on Ometepe Island. However, each installation met with limited success. Completing the design and fabrication of the prototype by Spring Break left little time for testing. The shortened schedule and challenges in communication with residents of the island resulted in only minor 
improvements in the designs from 2005-06 to 2006-07 and from 2006-07 to 2007-08. Failures seen in the 2005-06 system were not assessed until the 2006-07 trip, stretching the design cycle into years. During the 2007-08 trip, many improvements were made in the original design and the earlier prototypes were retrofitted to reflect these improvements. Although all three systems are currently inoperable, a new team of students will be testing the previous designs to determine the cause of failure in each system.

\section{B. The Alumni Survey}

To determine the effects the Ometepe Projects had on the peers of the students directly involved in the projects, a survey was sent to all alumni who experienced the senior design course sequence between the academic calendar years of 2002-03 and 2007-08. One question on the survey separated these alumni responses by the year in which they completed GE 498 so that four categories could be created for analyzing the results:

- Those alumni who completed GE 498 in the two years before the Ometepe Project was proposed (2003 and 2004 graduates);

- Those alumni who completed GE 498 in 2005, the first year the Ometepe Project was attempted without the option of travel;

- Those alumni who completed GE 498 in the three years that the Ometepe Project students traveled to the island (2006-2008 graduates), excluding those alumni who were directly involved in the Ometepe Project; and

- Those alumni who were directly involved in the Ometepe Project from 2006 to 2008.

Two distinctions have been made for creating these four categories. The 2003 and 2004 graduates experienced GE 498 without any students involved in an international service-learning design project. The 2006-2008 graduates all experienced GE 498 with students who traveled to the island. The 2005 graduates experienced GE 498 with students who were tackling a service project for a village in Nicaragua. However, these students had little communication with the residents of the island and did not travel. A second distinction is between those who were involved in the Ometepe Project and those who were not. This ensures that the Ometepe Project alumni responses do not unnecessarily bias the results. The 2005 alumni responses were divided in a similar way; the Ometepe Project alumni from 2005 were not included in the results.

\section{DISCUSSION OF RESULTS}

The alumni were surveyed on their achievement of the course objectives for GE 498, their desire for service-related activities, and their social and cultural awareness. These results can be seen in Table I. In this table, the average survey rating is given for the four categories discussed previously. These ratings are on a five-point Likert scale where $1=$ "No" and $5=$ "Yes". These categories, including the number of respondents for each are:

- 2003-2004 graduates (28 respondents - 12 respondents from 2003 graduates, 16 from 2004 graduates);

- 2005 graduates (12 respondents);

- 2006-2008 graduates, excluding the Ometepe Project alumni (79 respondents - 22, 26, and 31 respondents from 2006, 2007, and 2008 graduates, respectively); and

- $\quad$ the Ometepe Project alumni from 2006-2008 (14 respondents). 
Due to the limited number of responses for the 2005 graduates and the Ometepe Project alumni, these are not statistically separated from the 2003-2004 responses and the 2006-2008 responses. However, they are included as reference information in support of the conclusions drawn.

\section{TABLE I}

RESULTS OF THE ALUMNI SURVEY DIVIDED INTO FOUR CATEGORIES: 1.) 2003 AND 2004 GRADUATES, 2.$) 2005$ GRADUATES, 3.) 2006-2008 GRADUATES NOT INVOLVED IN THE OMETEPE PROJECT, AND 4.) 2006-2008 OMETEPE PROJECT GRADUATES. RESPONSES TO EACH QUESTION WERE ON A 5-POINT LIKERT SCALE WHERE $1=$ "NO” AND $5=$ "YES". THE SHADING HIGHLIGHTS THE TWO CATEGORIES THAT WILL BE THE FOCUS OF THE DISCUSSION OF RESULTS.

\begin{tabular}{|c|c|c|c|c|c|}
\hline \# & Course Learning Objectives & $\begin{array}{l}2003- \\
2004\end{array}$ & 2005 & $\begin{array}{l}2006- \\
2008\end{array}$ & $\begin{array}{l}\text { Ometepe } \\
\text { Project }\end{array}$ \\
\hline 1 & $\begin{array}{l}\text { Can you function effectively as a member of a multidisciplinary } \\
\text { team? }\end{array}$ & 4.71 & 4.92 & 4.81 & 4.71 \\
\hline 2 & $\begin{array}{l}\text { Can you build a physical prototype of a product based on } \\
\text { engineering drawings, flowcharts, and circuit schematics? }\end{array}$ & 4.00 & 4.25 & 4.49 & 4.36 \\
\hline 3 & Can you effectively present oral progress reports? & 4.57 & 4.67 & 4.60 & 4.79 \\
\hline 4 & $\begin{array}{l}\text { Can you write an effective technical document to summarize your } \\
\text { work? }\end{array}$ & 4.36 & 4.50 & 4.39 & 4.50 \\
\hline 5 & $\begin{array}{l}\text { Can you prepare and present an effective technical oral report to } \\
\text { summarize your design, prototype, and test results? }\end{array}$ & 4.52 & 4.67 & 4.53 & 4.86 \\
\hline 6 & $\begin{array}{l}\text { Can you use design specifications and a test plan to evaluate the } \\
\text { success of a physical prototype? }\end{array}$ & 4.25 & 4.75 & 4.41 & 4.21 \\
\hline 7 & $\begin{array}{l}\text { Can you incorporate engineering standards into your design } \\
\text { project? }\end{array}$ & 4.07 & 4.58 & 4.37 & 4.07 \\
\hline 8 & $\begin{array}{l}\text { Can you create quality audio/visual materials to support oral } \\
\text { presentations and written reports? }\end{array}$ & 4.46 & 4.83 & 4.42 & 4.43 \\
\hline 9 & $\begin{array}{l}\text { Can you identify important parameters to be measured to check if } \\
\text { your design requirements are met? }\end{array}$ & 4.29 & 4.75 & 4.58 & 4.36 \\
\hline 10 & $\begin{array}{l}\text { Can you synthesize and integrate previous knowledge in } \\
\text { mathematics, science, and engineering to assist in the achievement } \\
\text { of a successful design? }\end{array}$ & 4.46 & 4.67 & 4.61 & 4.36 \\
\hline \multirow[t]{2}{*}{11} & Can you prepare a budget and cost analysis of your project? & 4.00 & 4.17 & 4.08 & 4.21 \\
\hline & \multicolumn{5}{|l|}{ Service } \\
\hline 12 & $\begin{array}{l}\text { Do you feel your senior design project experience inspired you to } \\
\text { help others? }\end{array}$ & 1.64 & 2.67 & 3.01 & 4.79 \\
\hline \multirow[t]{2}{*}{13} & $\begin{array}{l}\text { Do you feel your senior design project experience instilled in you } \\
\text { a, or enhanced an existing, desire to help others? }\end{array}$ & 1.71 & 2.58 & 2.95 & 4.79 \\
\hline & \multicolumn{5}{|l|}{ Social and Cultural Awareness } \\
\hline 14 & $\begin{array}{l}\text { Do you feel your senior design project experience enhanced your } \\
\text { knowledge of other cultures? }\end{array}$ & 1.56 & 1.92 & 1.98 & 4.71 \\
\hline 15 & $\begin{array}{l}\text { Do you feel your senior design project experience opened your } \\
\text { eyes to social issues in other countries? }\end{array}$ & 1.19 & 1.33 & 1.99 & 4.79 \\
\hline 16 & $\begin{array}{l}\text { Do you feel your senior design project experience opened your } \\
\text { eyes to social issues more local to you? }\end{array}$ & 1.19 & 1.75 & 2.34 & 4.00 \\
\hline 17 & $\begin{array}{l}\text { Do you feel your senior design project experience helped connect } \\
\text { you to the world around you? }\end{array}$ & 1.48 & 2.5 & 2.64 & 4.71 \\
\hline 18 & $\begin{array}{l}\text { Do you feel your senior design project experience changed how } \\
\text { you interact with the world around you? }\end{array}$ & 1.78 & 2.67 & 2.61 & 4.64 \\
\hline
\end{tabular}

Table II shows a more detailed analysis between the 2003-2004 survey ratings and the 20062008 survey ratings for those questions that showed a significant change. In this table, the 
percentage change from 2003-2004 to 2006-2008 is given as well as the p-value from the Student-t distribution comparison of means that distinguishes between these two categories.

TABLE II

SigNIFICANT RESULTS OF THE ALUMNI SURVEY. THIS TABLE HIGHLIGHTS THE NOTABLE CHANGES BETWEEN THE 20032004 GRADUATES AND THE 2006-2008 GRADUATES. THE PERCENTAGE INCREASE FROM 2003-2004 TO 2006 -2008 IS INCLUDED AS WELL AS THE P-VALUE FROM THE STUDENTS-T COMPARISON OF THE MEANS BETWEEN THESE TWO

\begin{tabular}{|c|c|c|c|c|c|}
\hline$\#$ & Course Learning Objectives & $\begin{array}{l}2003- \\
2004\end{array}$ & $\begin{array}{l}2006- \\
2008\end{array}$ & $\begin{array}{c}\text { Percent } \\
\text { Increase in } \\
\text { Rating } \\
\end{array}$ & p-value \\
\hline 2 & $\begin{array}{l}\text { Can you build a physical prototype of a product based on } \\
\text { engineering drawings, flowcharts, and circuit schematics? }\end{array}$ & 4.00 & 4.49 & $12.3 \%$ & 0.004 \\
\hline 7 & $\begin{array}{l}\text { Can you incorporate engineering standards into your design } \\
\text { project? }\end{array}$ & 4.07 & 4.37 & $7.4 \%$ & 0.123 \\
\hline \multirow[t]{2}{*}{9} & $\begin{array}{l}\text { Can you identify important parameters to be measured to } \\
\text { check if your design requirements are met? }\end{array}$ & 4.29 & 4.58 & $6.8 \%$ & 0.033 \\
\hline & Service & & & & \\
\hline 12 & $\begin{array}{l}\text { Do you feel your senior design project experience inspired } \\
\text { you to help others? }\end{array}$ & 1.64 & 3.01 & $83.5 \%$ & $<0.0001$ \\
\hline \multirow[t]{2}{*}{13} & $\begin{array}{l}\text { Do you feel your senior design project experience instilled } \\
\text { in you a, or enhanced an existing, desire to help others? }\end{array}$ & 1.71 & 2.95 & $72.5 \%$ & $<0.0001$ \\
\hline & Social and Cultural Awareness & & & & \\
\hline 14 & $\begin{array}{l}\text { Do you feel your senior design project experience } \\
\text { enhanced your knowledge of other cultures? }\end{array}$ & 1.56 & 1.98 & $26.9 \%$ & 0.071 \\
\hline 15 & $\begin{array}{l}\text { Do you feel your senior design project experience opened } \\
\text { your eyes to social issues in other countries? }\end{array}$ & 1.19 & 1.99 & $67.2 \%$ & 0.001 \\
\hline 16 & $\begin{array}{l}\text { Do you feel your senior design project experience opened } \\
\text { your eyes to social issues more local to you? }\end{array}$ & 1.19 & 2.34 & $96.6 \%$ & $<0.0001$ \\
\hline 17 & $\begin{array}{l}\text { Do you feel your senior design project experience helped } \\
\text { connect you to the world around you? }\end{array}$ & 1.48 & 2.64 & $78.4 \%$ & $<0.0001$ \\
\hline 18 & $\begin{array}{l}\text { Do you feel your senior design project experience changed } \\
\text { how you interact with the world around you? }\end{array}$ & 1.78 & 2.61 & $46.6 \%$ & 0.001 \\
\hline
\end{tabular}

\section{A. GE 498 Learning Objectives}

The learning objectives from the second semester of the course sequence, GE 498, were included in the alumni survey to determine if changes to the course structure resulted in any significant changes to the alumni self-assessment. As shown in Table I, the four categories of alumni rated their abilities to complete the learning objectives comparable to one another with three notable exceptions. Of the three that did see a significant change, all three were improvements, with the largest of these improving by 12\% (Table II). The cause of the improvement for these three questions is likely due to incremental changes to the format of the course and to the course content. Figure 1 shows an example of a year-to-year progression of the alumni ratings for Question 6, a question that was not rated significantly different from 2003-04 (4.25 average rating) to 2006-08 (4.41 average rating). As seen in Figure 1, the 2003 and 2007 changes to the course result in only minor, though noticeable, changes in the alumni ratings. We would expect 
any larger changes to be outside of the control of the course content and due to other changes such as the types of projects offered.

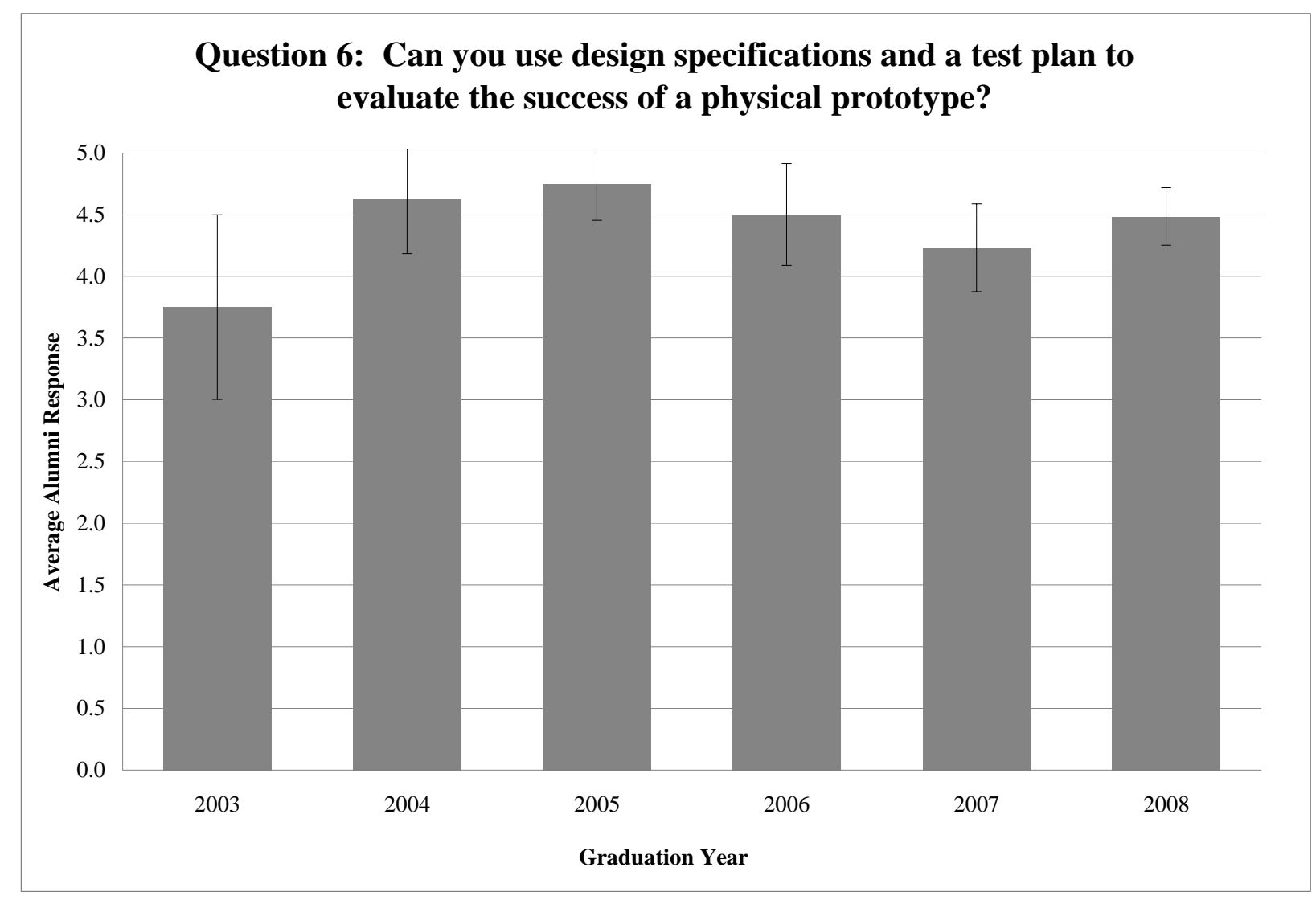

FIGURE 1

A YEAR-BY-YEAR PROGRESSION OF THE ALUMNI RATINGS FOR QUESTION 6 INCLUDING CONFIDENCE INTERVALS. THIS PROGRESSION EXCLUDES THE ALUMNI RATINGS FROM THOSE STUDENTS INVOLVED DIRECTLY WITH THE OMETEPE PROJECT. THE PROGRESSION HIGHLIGHTS THE EFFECTS OF THE COURSE CHANGES DURING THE SUMMERS OF 2003 AND

\section{B. Service}

For Questions 12 and 13, the alumni ratings increase significantly between 2003-04 (1.64 average rating for Question 12 and 1.71 average rating for Question 13) and 2006-08 (3.01 average rating for Question 12 and 2.95 average rating for Question 13). Year-by-year progressions of the ratings to these two questions can be seen in Figures 2 and 3. Although the separation between average scores is not statistically significant on a year-to-year basis, these progressions allow us to make some hypotheses about why the differences exist between the 2003-04 and 2006-08 alumni ratings. In both Figures 2 and 3, upward trends exist. It is likely that this is due to the Ometepe Project students' enthusiasm for their project as illustrated by their high ratings for these questions (4.79 average rating for both questions) and the dissemination of their energy and insight through the many presentations as well as the close relationship that all 50 (or so) senior design students share. 


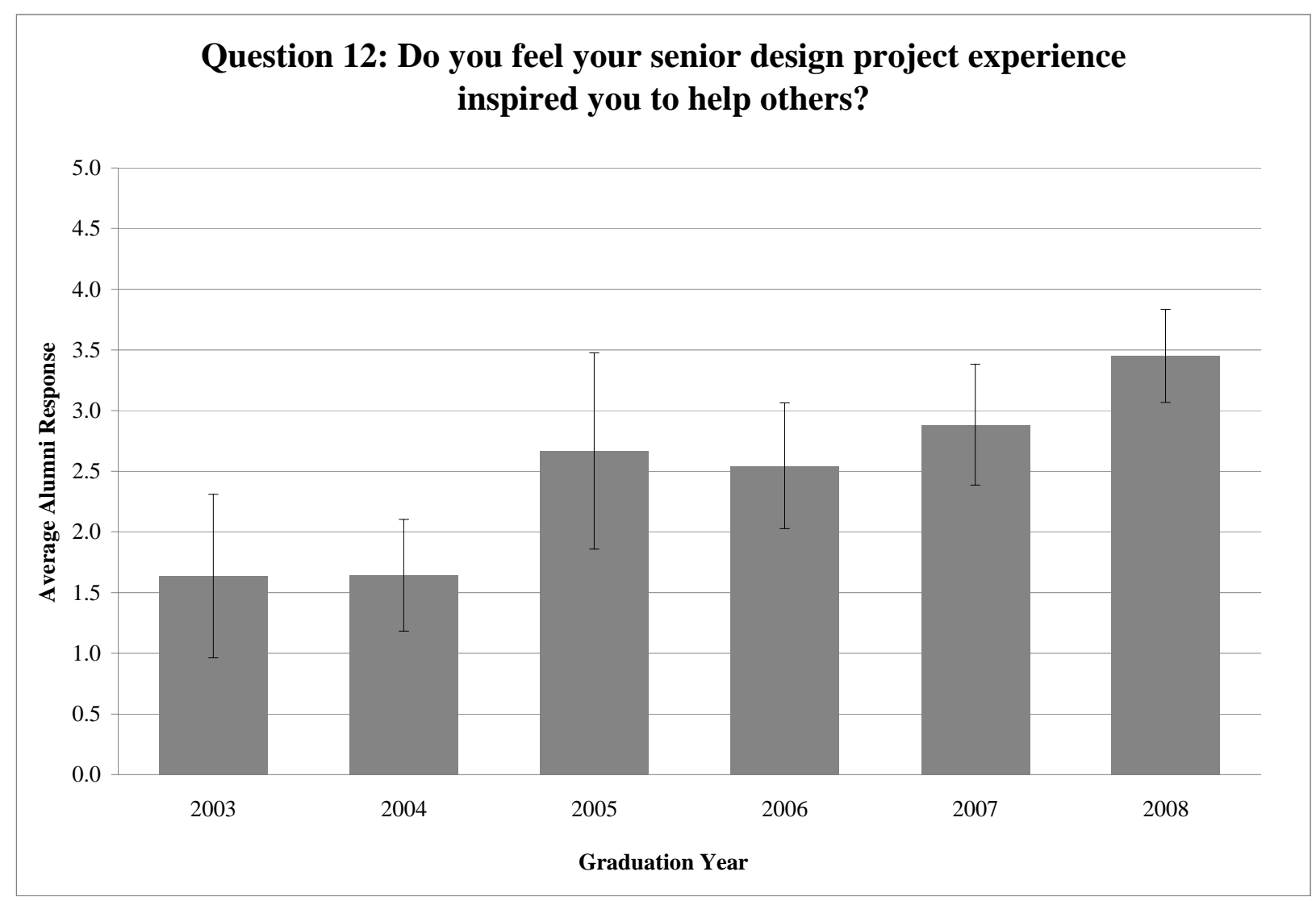

FIGURE 2

A YEAR-BY-YEAR PROGRESSION OF THE ALUMNI RATINGS FOR QUESTION 12 INCLUDING CONFIDENCE INTERVALS. THIS PROGRESSION EXCLUDES THE ALUMNI RATINGS FROM THOSE STUDENTS INVOLVED DIRECTLY WITH THE OMETEPE PROJECT. 


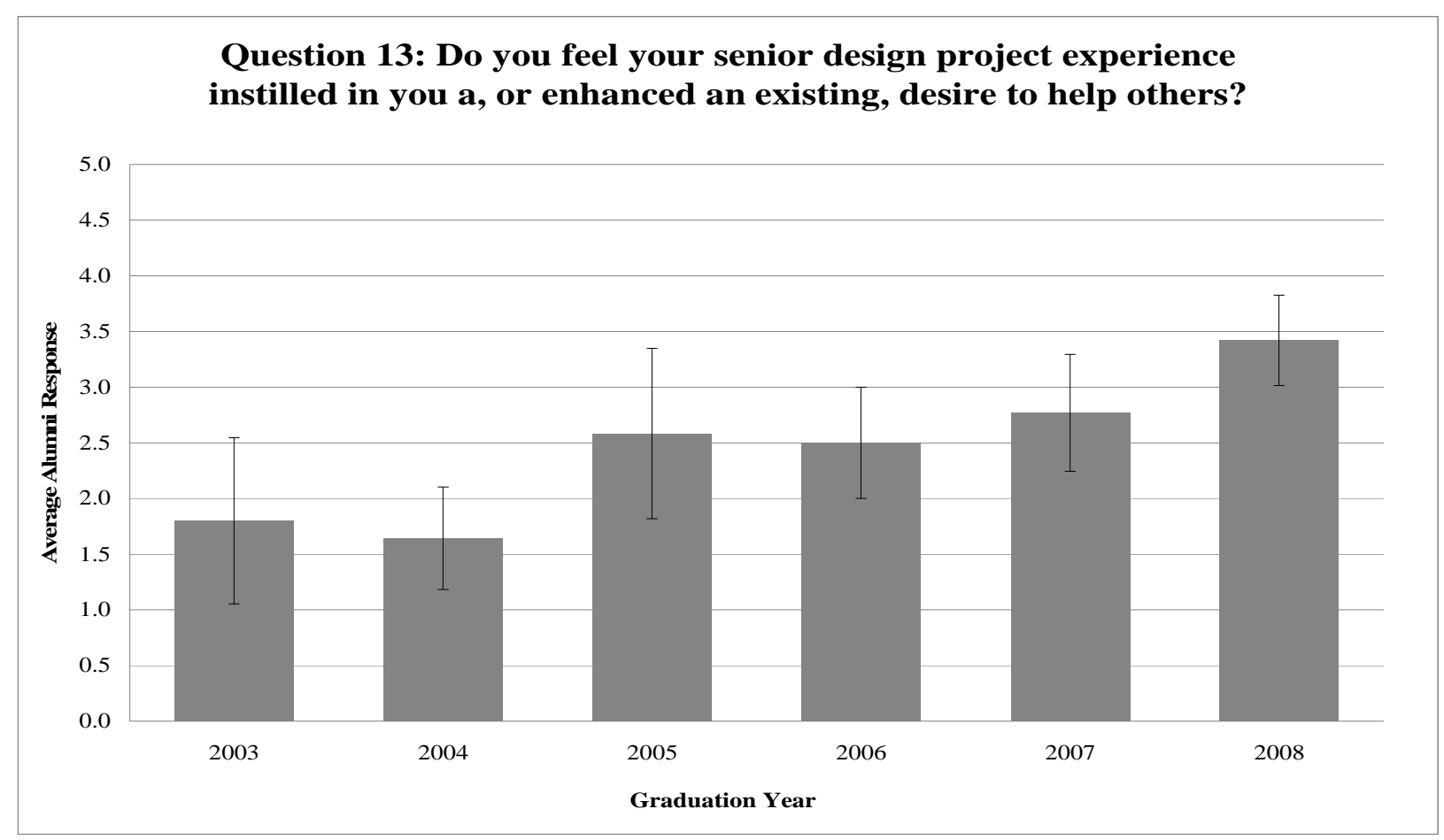

FIGURE 3

A YEAR-BY-YEAR PROGRESSION OF THE ALUMNI RATINGS FOR QUESTION 13 INCLUDING CONFIDENCE INTERVALS. THIS PROGRESSION EXCLUDES THE ALUMNI RATINGS FROM THOSE STUDENTS INVOLVED DIRECTLY WITH THE OMETEPE

PROJECT.

Another explanation for the increased ratings for Questions 12 and 13 could be related to the types of projects offered in a given academic year. Table III lists the design projects developed during each year of the study. Some projects fulfill multiple categories, such as a fire-fighting robot that was developed for a student competition in 2003-2005. The end goal of the competition was to provide an autonomous system to help save the lives of firefighters. Therefore, this project is categorized as both a service project and for a student competition. The number of projects that are service-oriented does not change significantly from year to year.

TABLE III

TYPES OF PROJECTS DEVELOPED IN GE 497/498 DURING THE PERIOD INCLUDED IN THIS STUDY.

\begin{tabular}{|c|c|c|c|c|c|c|c|}
\hline \multirow{2}{*}{$\begin{array}{c}\text { Academic } \\
\text { year }\end{array}$} & \multicolumn{2}{|c|}{ Service } & \multirow{2}{*}{$\begin{array}{l}\text { Indust } \\
\text { ry }\end{array}$} & \multirow{2}{*}{$\begin{array}{l}\text { Faculty } \\
\text { Research }\end{array}$} & \multirow{2}{*}{$\begin{array}{c}\text { Student } \\
\text { Competition }\end{array}$} & \multirow{2}{*}{$\begin{array}{l}\text { Academic / } \\
\text { other }\end{array}$} & \multirow{2}{*}{$\begin{array}{c}\text { Number of } \\
\text { Projects }\end{array}$} \\
\hline & International & Other & & & & & \\
\hline 2002-03 & - & 3 & - & 1 & 3 & 5 & 10 \\
\hline 2003-04 & - & 2 & - & 1 & 2 & 8 & 12 \\
\hline 2004-05 & 1 & 3 & - & - & 2 & 3 & 8 \\
\hline 2005-06 & 1 & 2 & - & 1 & 3 & 3 & 10 \\
\hline 2006-07 & 1 & 1 & 1 & 2 & 3 & 2 & 10 \\
\hline 2007-08 & 1 & 2 & 1 & 1 & 1 & 4 & 10 \\
\hline
\end{tabular}




\section{Social and Cultural Awareness}

The responses to Questions 14 and 15 show a significant increase in the ratings from the 20032004 alumni to the peers of the Ometepe Project in 2006-2008 (Table II). The rating for Question 14 increased by $26.9 \%$ and by 67.2\% for Question 15. The statistical analysis shows that it is unlikely that either increase is due to random chance.

Another interesting result is that although ratings to both questions increased significantly, the increase in the rating for Question 14 (26.9\%) was less than that of Question 15 (67.2\%). Figures 4 and 5 show year-by-year progressions of the alumni responses to these two questions. Also of interest is that the confidence intervals for the 2003-04 and 2006-08 ratings overlap more for Question 14 than those for Question 15. In other words, the Student-t distribution p-value of Question 14 (0.071) is higher than that of Question 15 (0.001). This means that there is a 7.1\% chance that the increase in rating for Question 14 could be a coincidence, whereas there is only a $0.1 \%$ chance that the increased rating for Question 15 would be due to random chance. The results suggest that although having projects similar to the Ometepe Project can increase awareness of social issues in other countries, it does not necessarily mean that these same students will feel more knowledgeable about the cultures. The students involved in the Ometepe Project made many presentations regarding the need of the community and the system that had been designed to address this need. However, these presentations were more focused on the technical aspects of the design and how it was related to the societal need and less on the effect the design would have on the local culture. Furthermore, due to the intensity and shortened schedule, teaching the Ometepe Project students about the local culture was limited to personal experiences from faculty who had been to the island. The team was exposed to the cultural aspects of their project more directly when they traveled to the work site and interacted with the community members. However, this experience occurred in the last half of the second semester of the project. Only one team presentation and two individual presentations followed this trip, therefore limiting the cultural information disseminated to the rest of the class. 


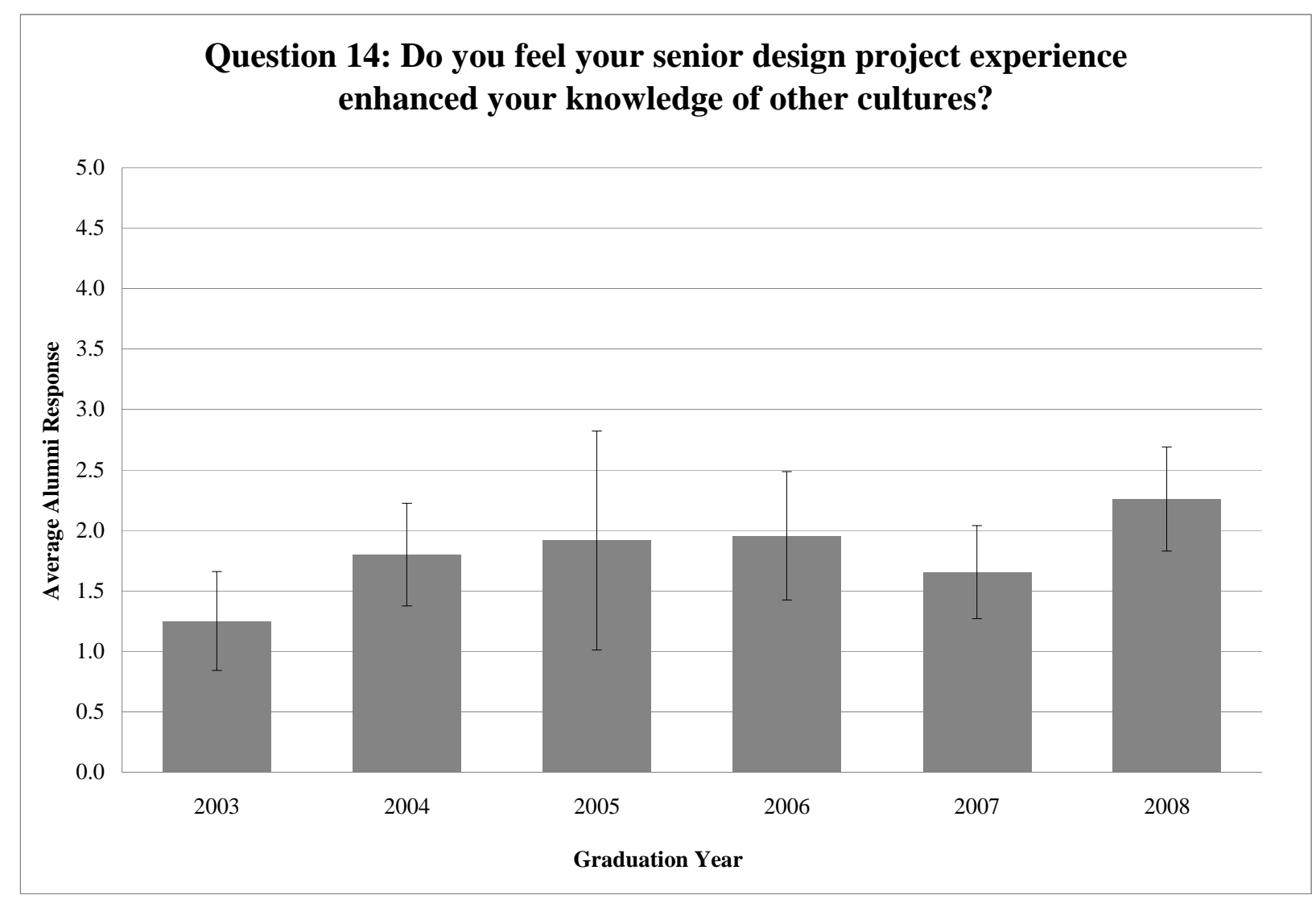

FIGURE 4

A YEAR-BY-YEAR PROGRESSION OF THE ALUMNI RATINGS FOR QUESTION 14 INCLUDING CONFIDENCE INTERVALS. THIS PROGRESSION EXCLUDES THE ALUMNI RATINGS FROM THOSE STUDENTS INVOLVED DIRECTLY WITH THE OMETEPE

PROJECT.

The results of the social and cultural awareness section of the survey suggest that more attention should be given to enhance these students' education by providing more cultural background earlier and to have the team present on these issues to the entire course during their individual updates. Borg and Zitomer [2008] assigned reading material for their teams which could provide the necessary background material that would improve the project experience for our students. 


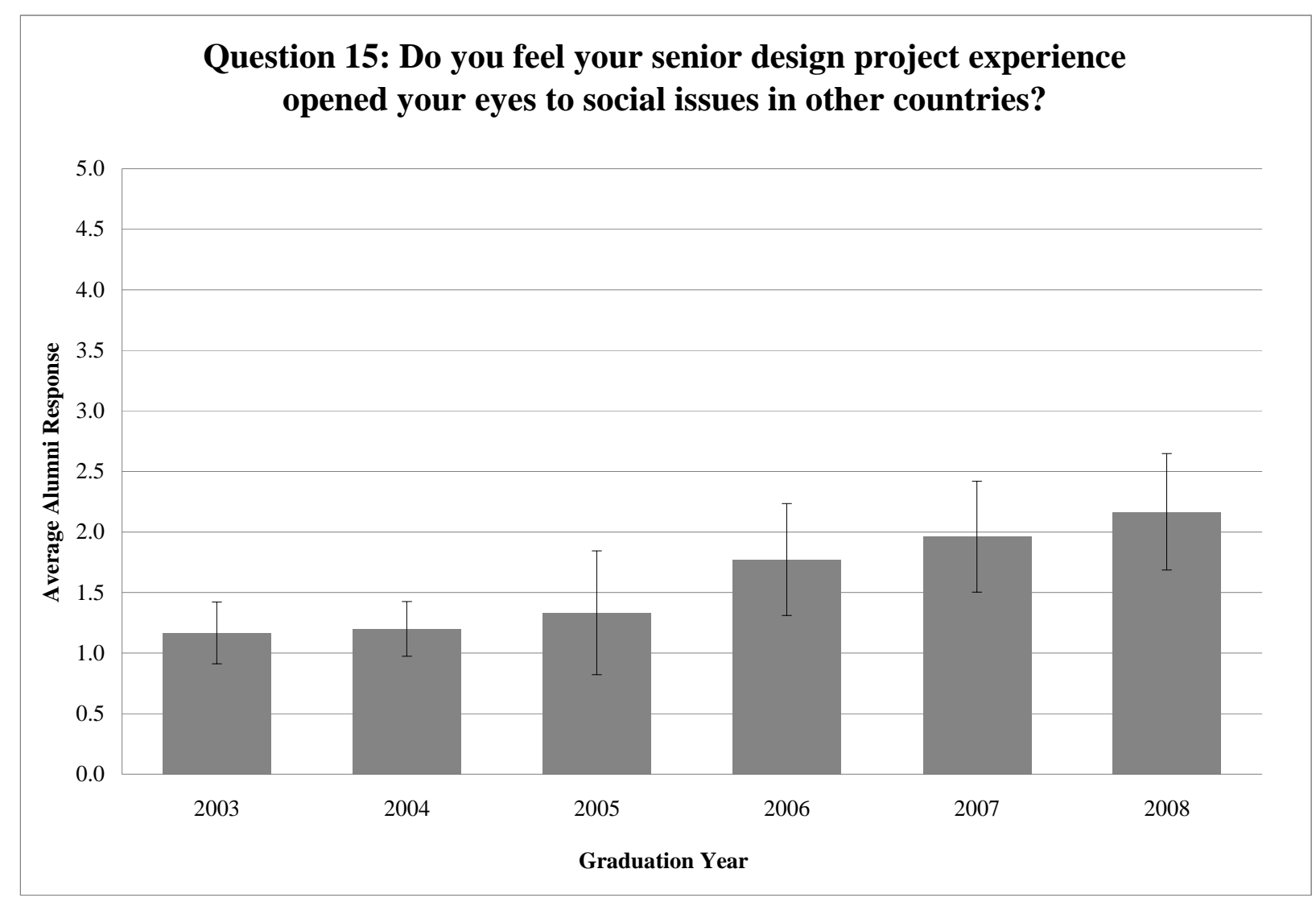

FIGURE 5

A YEAR-BY-YEAR PROGRESSION OF THE ALUMNI RATINGS FOR QUESTION 15 INCLUDING CONFIDENCE INTERVALS. THIS PROGRESSION EXCLUDES THE ALUMNI RATINGS FROM THOSE STUDENTS INVOLVED DIRECTLY WITH THE OMETEPE

\section{Conclusions}

A survey of alumni who had experienced the senior design course at Valparaiso University was conducted to determine if an international service-learning design project had positive effects on the peers of those students directly involved in the project. The results of this survey show that:

- Changes made to the course did not result in significant impact on the learning objectives;

- Students not directly involved in the Ometepe Project felt a stronger desire to participate in service-related activities than those alumni who experienced the course when an international service-learning design project was not offered; and

- Students not directly involved in the Ometepe Project felt an increased awareness of social issues in other countries and an increased knowledge of other cultures than those alumni who experienced the course when an international service-learning design project was not offered

The results of the questions related to the learning objectives show that although the course was changed from year to year, it resulted in only minor impacts on the alumni responses. It is therefore possible to conclude that the impact on alumni desire to participate in service-related activities, their awareness of social issues in other countries, and their knowledge of other cultures was not impacted considerably by changes made to the course structure.

The alumni who were not directly involved in an international service-learning design project felt a stronger desire to participate in service related activities than their counterparts who 
experienced the design course in the two years of the survey when such a project was not offered. It is unlikely that this could be attributed to any changes made to the course structure or to the number of service-related projects offered. Without any information about these alumni before they took the course, it is impossible to determine if there existed any predisposition to service-related activities. However, the data collected show that a definite increase in the desire to participate in these activities did occur during the same years that the international servicelearning design project in Nicaragua was offered.

A similar finding occurred in the alumni responses to questions regarding their awareness of social issues in other countries and their knowledge of other cultures. Again, it is unknown whether or not these alumni started the course sequence with an increased predisposition. But, again, the data show that a statistically significant increase in these items occurred during the same years that the Ometepe Project was offered.

A surprising result of the survey showed that although alumni were more aware of social issues in other countries, their increased knowledge of other cultures was less noticeable. This is likely due to the technical focus of the course and it points to an area for improvement in how this type of project is integrated into this course. To better prepare students for immersion in a new culture, a more explicit introduction to this culture should be made. Providing the cultural background to those directly involved in the Ometepe Project earlier as Borg and Zitomer [2008] suggest, may help provide their peers exposure to this culture as well.

In general, international service projects will result in educational benefits to the teams involved in these projects. Based on the survey results, these educational benefits can also impact others in the course, even if this is not the intended goal. Furthermore, the results of this survey can help others to more consciously direct their international service projects towards those students who are not directly involved in these projects. The emphasis on student presentations keeps everyone in the course updated on the progress of each project, which can help disseminate the experience, and therefore the benefits, of an international service team throughout the entire course.

\section{ACKNOWLEDGMENT}

The author would like to acknowledge the students who participated in this survey, specifically those students enrolled in GE 497/498 during the fall and spring semesters of 2003-2008. Ms. Laura Sanders also deserves thanks for helping implement and organize this survey.

The author would also like to acknowledge the 15 students who have been involved in the Ometepe Project during the 2005-2008 academic years: Tommy Bendlak, Joel Benscoter, Joanne Borchert, Becca Crocker, Mike Gibbs, Matt Hoovey, Sameer Kaul, Daniel Laidig, Anthony Ortiz, Kristin Painting, Mike Schallhorn, Tom Shiraki, Erik Smith, Erin Swanson, and Eric Vurva. Their dedication and willingness to go beyond the course requirements have had an impact on the residents of Ometepe Island as well as the Valparaiso University community. 


\section{REFERENCES}

Accreditation Board for Engineering and Technology (ABET), 2004, Criteria for Accrediting Engineering Programs, Baltimore, MD.

Borg, J. P., and D. H. Zitomer, "Dual-team Model for International Service Learning in Engineering: Remote Solar Water Pumping in Guatemala,” Journal of Professional Issues in Engineering Education and Practice 134, no. 2 (2008), 178-185.

Freeman, S., D. Matson, G. Sharpe, and C. Swan, "International Citizenship and Global Service Leadership-The Role of Interdisciplinary Teams in Engineering Education," in Proceedings of the 2006 American Society for Engineering Education Annual Conference \& Exposition, Chicago, IL (2006).

Green, M. G., K. L. Wood, S. H. Vanderleest, F. T. Duda, C. Erikson, and N. Van Gaalen, "ServiceLearning Approaches to International Humanitarian Design Projects: A Model Based on Experiences of Faith-Based Institutions," in Proceedings of the 2004 American Society for Engineering Education Annual Conference \& Exposition, Salt Lake City, UT (2004).

Hagenberger, M., P. Johnson, D. Tougaw, J. Will, M. Budnik, and K. Sevener, "Managing Senior Projects: Educating Graduates and Undergraduates in a Senior Project Course," in Proceedings of the 2007 American Society for Engineering Education Annual Conference \& Exposition, Honolulu, HA (2007).

Jiusto, S., and D. DiBiasio, "Experiential Learning Environments: Do They Prepare Our Students to be Self-Directed, Life-Long Learners?” Journal of Engineering Education 95, no. 3 (2006), 195-204.

Johnson, P. E., K. Sevener, D. Tougaw, and J. Will, "Balancing Learning Objectives and Success in a Multidisciplinary Senior Design Project," in Proceedings of the 2007 American Society for Engineering Education National Conference, Honolulu, HA (2007).

Johnson, P. E., M. Budnik, K. Sevener, and J. Will, "Motivation, Inspiration, and Economics of an International Service Project," in Proceedings of the National Capstone Design Course Conference, Boulder, CO (2007).

Phillips, L., A. Brady, and K. Jousma, "Interdisciplinary International Senior Design: How Service Learning Projects in Developing Countries Support ABET Accreditation,” in Proceedings of the 2007American Society for Engineering Education Annual Conference \& Exposition, Honolulu, HA (2007).

Tougaw, D. and M. Barrett, "Determination of Individual Performance on a Team," in Proceedings of the 2005 American Society for Engineering Education Illinois/Indiana Sectional Conference, Chicago, IL (2002), 124-127.

Tougaw, D. and J. Will, “An Innovative Multidisciplinary Capstone Design Course Sequence,” in Proceedings of the 2003 American Society for Engineering Education Annual Conference \& Exposition, Nashville, TN (2003). 
Tougaw, D. and J. D. Will, “Integrating National Robotic Competitions into Multidisciplinary Senior Project Courses," in Proceedings of the 2005 American Society for Engineering Education Illinois/Indiana Sectional Conference, DeKalb, IL (2005).

Tougaw, D., J. Will, P. Johnson, M. Hagenberger, and M. Budnik, “Integrating Entrepreneurship into Senior Design Projects," in Proceedings of the National Collegiate Inventors and Innovators Alliance Annual Conference, Tampa, FL (2007).

Vader, D., C. A. Erikson, and J. W. Eby, "Cross-Cultural Service Learning for Responsible Engineering Graduates,” In Proceedings of the 2006 American Society for Engineering Education Annual Conference \& Exposition, Charlotte, NC (1999). 